\title{
Risk of asthma and environmental exposure to glyphosate in an ecological study
}

\author{
Medardo Avila-Vázquez ${ }^{1}$, Flavia Difilippo ${ }^{1}$, Bryan Mac Lean $^{1}$, and Eduardo Maturano ${ }^{1}$ \\ ${ }^{1}$ Universidad Nacional de Cordoba
}

August 13, 2020

\begin{abstract}
Background: There is strong evidence of the link between asthma and occupational exposure to pesticides and glyphosate in agricultural workers, but it is limited on environmental or residential exposure to these chemicals. Methods: We analyze asthma prevalence in an agricultural town with high use of pesticides, mainly glyphosate with an ecological study conducted in Monte Maíz, Argentina, composed of a chemical and environmental analysis to determine the burden of exposure to glyphosate and pesticides in general, and a cross-sectional asthma study that uses the methodological criteria of the International Study of Asthma and Allergies in Childhood (ISAAC); the prevalence's found in Monte Maíz are compared with the results of ISAAC in Argentine cities with low exposure to pesticides. Results: In Monte Maíz high and preponderant levels of glyphosate were found in the soil and in corn husk and soybean powder. The environmental exposure burden to pesticides was 121 kilos, for glyphosate 81 kilos per person per year, while this burden in the entire country is 7.9 and 6 kilos respectively. The found asthma prevalences were several times higher than those of reference in all ages, the risk of asthma in children of 13 and 14 years old, with respect to those of three large Argentine cities is: OR of 4.64 (CI: 3, $26-6.60$ ). Conclusion: These results highlight a relationship between environmental and residential exposure to glyphosate and high prevalence of asthma, while experimental studies support the biological plausibility of this association.
\end{abstract}

\section{Hosted file}

Main_Text_File.doc available at https://authorea.com/users/350829/articles/475560-risk-ofasthma-and-environmental-exposure-to-glyphosate-in-an-ecological-study

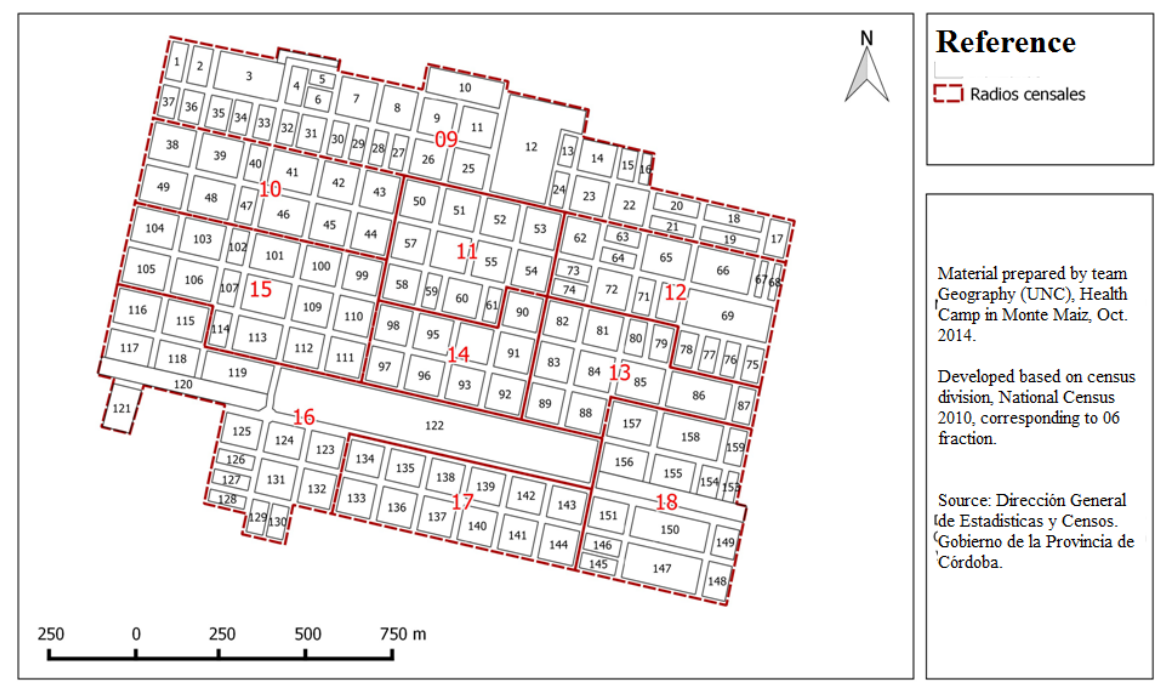




\section{Hosted file}

tabla 1 Population surveyed Characteristics, absolute numbers and percentages.doc available at https://authorea.com/users/350829/articles/475560-risk-of-asthma-and-environmentalexposure-to-glyphosate-in-an-ecological-study

\section{Hosted file}

Tabla $n \backslash$ selectlanguage\{ngerman\}으 2.docx available at https://authorea.com/users/350829/ articles/475560-risk-of-asthma-and-environmental-exposure-to-glyphosate-in-anecological-study

\section{Hosted file}

tabla $\mathrm{n}$ ㅇ 3.doc available at https://authorea.com/users/350829/articles/475560-risk-ofasthma-and-environmental-exposure-to-glyphosate-in-an-ecological-study

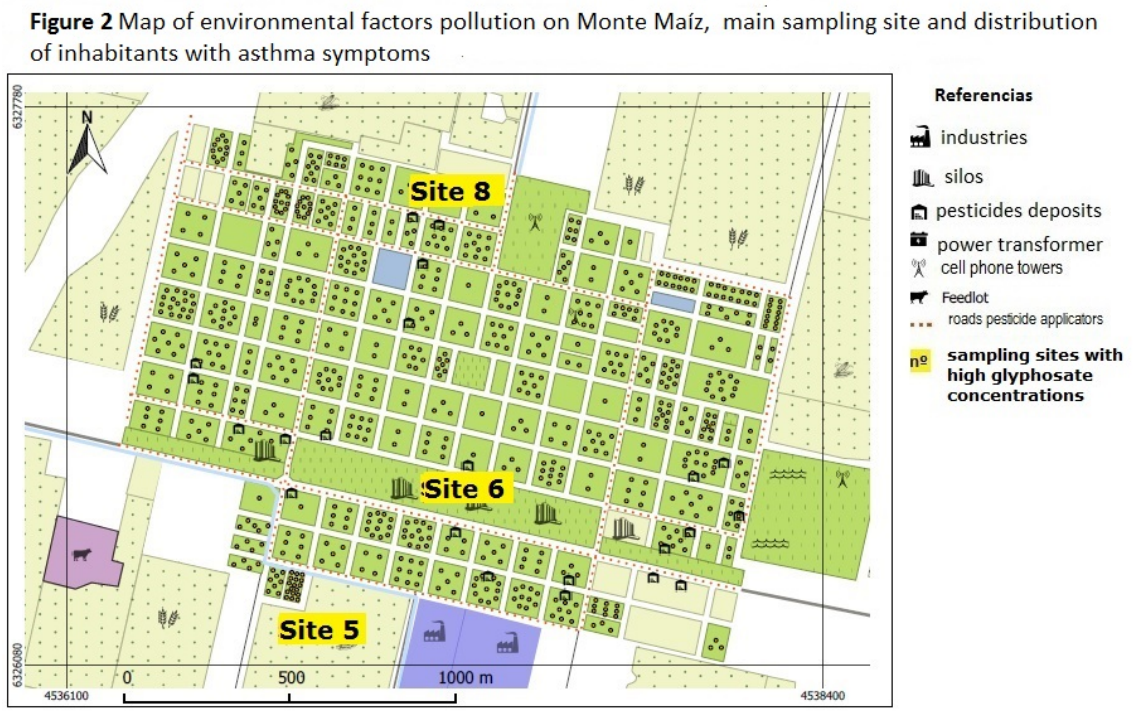

\section{Hosted file}

table 4 measurements pesticides.doc available at https://authorea.com/users/350829/articles/ 475560-risk-of-asthma-and-environmental-exposure-to-glyphosate-in-an-ecological-study 